\title{
The Role of Communication in the Process of Forming Market-Oriented Party (Mop): Its Importance and Approaches
}

\author{
Koay Hean Wei \& Khairiah Salwa Mokhtar \\ University Sains Malaysia, Malaysia \\ shinywatertree@yahoo.co.uk, khairiah@usm.my
}

\begin{abstract}
This paper discusses the role of communication in the process of market-oriented political modeling. Our theoretical framework benefits from the idea of Lees-Marshment's model, there are three types of parties that can help meet voters' needs: product-oriented party (POP), sales-oriented party (SOP) and market-oriented party (MOP). The focus here is MOP, which means developing political policies on the ground of voters' needs to gain from the voter "market". The MOP approach relies heavily on effective partyvoter communication, before, during and after an election. Specifically, the communication aspect in the process of the MOP approach is discussed, which covers political marketing as a social or communication process in image-building and different approaches in such communication. Various communication modes in gathering voter information are compared in terms of advantages and disadvantages, especially in trustbuilding and two-way (both verbal and non-verbal) communications. Lastly, a section related to political canvassing is also presented.
\end{abstract}

Keywords: Political marketing, face-to-face canvassing, vote canvassing, Malaysian politics and elections.

\section{Introduction}

Political marketing is believed to be the most effective way to communicate with voters in promoting the image of political parties and candidates in an election. This research proposal aims to investigate the extent marketing-oriented model is being used by political parties to compete for support from voters. It also attempts to investigate the process of political marketing model used by political parties by focusing on the communication aspect in the process, which suits the Malaysian scenario. The methodology used for data collection is primary data such as interviewing with politicians in Penang and secondary data including published journals, books, statistics from electronic media and newspapers. This study investigates the political marketing model based on the research in political parties and candidates in Penang. In which ethnic politics very much reflects our multi-ethnic society. According to the Malaysian constitution, within five years after the prior election, a general election must be held. The political tsunami in 2008 witnessed opposition parties such as DAP and PKR win 11 out of 13 parliament constituencies of seats in Penang and became a very strong political party in Penang (The Star Online, 2008). The role of political marketing in facilitating such changes in voter trends is worth the researchers' attention. The next section explains the meaning of political marketing, which is a new concept in our country.

Political Marketing: According to Harrop (1990), political marketing is a global phenomenon in which parties from all corners of the world engage to a certain extent. It is based on the results in marketing research and covers everything related to a party's positioning in the voting market. Jennifer LeesMarshment's analysis of UK party behavior (2001a) identified three approached parties could take by becoming either: a product-oriented party (POP), a sales-oriented party (SOP) or a market-oriented party (MOP); the latter being perceived as the paradigm for a party seeking to win the election. Therefore, she argued that voters choose parties as consumers choose products. This idea attracts the politicians' attention to examine the extent to which marketing techniques and approaches are employed. According to Kavanagh $(1995,1996)$ and Scammell $(1995)$ political marketing is similar to electioneering, which includes a set of steps to study public opinions (before and after an election), to establish campaign communications and to evaluate their effectiveness. Political marketing is gaining widespread acceptance in developed countries (Baines, Harris, \& Lewis, 2002). It is important to close the gap between voters' needs and what the parties can offer. Since political marketing covers a very broad range of areas, it is worth examining parts of it separately, such as campaign communication.

Political Marketing in Malaysia: Political marketing is a relatively new idea for most Malaysians. Most Malaysians see the election as an elimination process, and not about competing ideologies. Since the 
formation of Malaysia as an independent country in 1963, Malaysia has never experienced a change in government. Election campaign seems to do more to persuade voters to vote for them rather than focus on efforts of political parties to serve the voters (Manikas \& Thornton, 2003). These phenomena show that political parties in Malaysia need to strengthen the marketing aspect and embrace the political marketing model to adapt to this new era. In other words, Malaysian political parties need to engage in more democratic practices to improve the image of political parties. Political parties can be seen as the intermediary between the government and the people in addition to resolving conflicts. However, Malaysia's political system has been criticized as outdated in its political image (Heufers, 2002). Moreover, voter turnout is declining steadily, probably due to political indifferences. Thus political parties could play a more effective role to increase voter turnout in the modern challenging era. Having introduced the meaning of political marketing, we will examine the communication process of political marketing.

\section{Literature Review}

The Process of Political Marketing: In the early 1990s, political marketing started being mentioned in political contests. Political marketing efforts used include political advertising, broadcasts and electoral speeches as well as a party's positioning in the electoral market (Harrop, 1990). It is a set of procedures to understand and examine public opinion before and in the process of an election campaign, to establish election communications and to evaluate their effects. It is analysis, planning, implementation and control of political and electoral campaigns to lead the parties' win in an election. According to Wring (1997), political marketing is the party's (or candidate's) analysis of public views and political competition to generate and introduce an advantageous offering to help materialize organizational and voters' goals. It is also concerned with the exchange of ideas with party members, media, potential funders and voters. It is a form of marketing to influence voters to vote for an individual or party. Thus it is closely associated with techniques employed to win an election (Butler\& Collins, 1994; Newman, 1994) in which it is predominantly a communication process.

Political Marketing as a Social Process: The concept and process of political marketing are being embraced by political parties in developed countries. Political marketing is preferred by political parties because of the value-added for candidates to build a relationship with the voters. During political marketing, politicians interact directly with the citizens to give a positive impression important in building a relationship with the voter. Thus, appropriate political marketing allows candidates to develop strong social relationships with voters which enables the politicians to understand the voters' needs. Therefore, this study can provide information to political parties and help them to identify suitable political marketing strategies for coming elections. Understanding the voters' needs is one of the most useful strategies a candidate can do (Piccoli, \& Ives, 2003). It allows the candidates to provide personal concerns to voters to gain better support (Gerber \& Green, 2000; Gerber, Green \& Larimer, 2008). It also puts the message that the candidates care enough to talk to voters one on one. Voters are often impressed by the fact that a politician takes the effort to meet and respond (Smith, 1995).

Thus, a properly planned political marketing model may be crucial for the political parties to take into consideration and to enhance the positive factors and avoid the factors that negatively affect the image of politicians. Through Lees-Marchment's MOP model, politicians are expected to listen to and to ask for clarification about things that they don't understand (Ryan, Carlton \& Ali, 1999). The political campaigning process can be illustrated meaningfully using political marketing concepts. Marketing planning is highly related to creating a competitive advantage. Its main purpose is to gain and retain public support for programs or ideologies. Focusing on target voter groups alongside other undecided ones is crucial to ensure success under a competitive political climate. Political marketing can improve the information flows from voters to parties and candidates, enabling politicians to better meet voters' needs. Political marketing also enhances better communication between politicians to the electorate. Thus, Scammell (1995) suggests that political marketing offers a guideline for parties or candidates to act under a competitive democracy process.

Approaches in Voter Contacts: Studies from researchers found out that voter contact approaches, including telephone, direct mail, and face-to-face canvassing are important tools to encourage voters to support the politicians in an election (Gerber \& Green, 2000; Gerber \& Green, 2001). In political marketing, voter contact 
is crucial to make sure all the information delivery to the voter is effective. Voter contact is an organized system in campaign programs to deliver a persuasive message to targeted voters through direct contact or indirect contact (Wielhouwer, 2000). In Malaysia's political system, direct contact includes face-to-face canvassing from a door-to-door, service centre, group gathering, public speaking and debate. Indirect contact includes email, political television advertisement, newspaper advertisement and telephone voter contact.

(A) Face-to-Face Contacts: Face-to-face communication includes public speaking, presentations, discussions, election debate and aspects of interpersonal communication. Public speaking in an election campaign means speaking to express or describe thoughts, feelings, or perceptions with vocal communication in words (Hornby, Wehmeier, Mclntosh, Turnbull, \& Ashby, 2005). Public speaking refers to the process of addressing a group in a planned, intentional way to disseminate information, exert influence, or entertain the audience. Thus, public speaking in election campaigns is one of the most fundamental methods for politicians to inform and influence the decision of listeners. It is noted for two advantages: (a) non-verbal messages such as body language and voice tone probably have greater impacts on the audience (Orna, Amalia, Green, \& Nitzan, 2004); (b) it also elicits a direct response.

(B) ICT Contacts: In Malaysia, the internet is on the rise in its importance as a political marketing tool. Internet technologies including email and blogs for political parties to enable faster communication and reach out to a wider audience. In September 2006, Malaysia has 13.5 million internet users (a 47.8\% internet penetration rate). Cyberspace has become the new battlefield for political campaigns, the latest elections benefit from cyber technologies such as websites, youtube and SMS to gain support from voters in Malaysia. This high internet penetration rate is said to have helped the PR win the election in 2008. The mainstream media (both electronic and print), which are partially owned by the political coalition in power now, hardly mention the opposition parties. In the $12^{\text {th }}$ election in the year 2008, the PR's blogs and websites were the most active in spreading their latest news and ideas. The PR's breakthrough in the 12th general election can be attributed to its successful cyberspace marketing. Internet reading influences voter decisions. Thus, the election results are largely determined by the people's perception of the current government and the way forward for the country. Internet media is advantageous in terms of easy access. It also has changed the way how we receive and debate political ideas, which will eventually influence the voting decision. This strategy is particularly useful to reach out to young generations and urban voters. It provides an alternative to break mainstream media monopolies controlled by the government.

(C) Comparing both Communication Modes: There are more modes of communication available in this ICT era in addition to face-to-face communication. Many researchers suggest that face-to-face canvassing is slowly replaced by computer-mediated communication (CMC) as a useful communication platform (Begley, 2004; Meijden \& Veenman, 2005). Technological adoption has shifted face-to-face canvassing to computermediated communication practices (Jonassen \& Kwon, 2001). The scope of CMC includes Facebook, Friendster blog, Skynet, and Twitter. CMC enables active two-way communication to gain support from many users (Miller, 2009). CMC is an inexpensive way for people to communicate and search the information more efficiently and productively. Besides that, CMC has the advantages of saving time, cost-effective, easy to use as compared to face-to-face communication (Provenzo, 1986). In addition, some researcher attempts to compare CMC and face-to-face communication and the studies observe that feedback and support in the computer environment are increasing. This means that technologies enable humans in the world to communicate more effectively and efficiently. For example, nowadays politicians can communicate with voters by using blogs, e-mail or Facebook to maintain communication. Therefore, researchers concluded that CMC had changed our reliance on traditional communication modes, such as face-to-face canvassing (Meijden \& Veenman, 2005; Miller, 2009).

\section{Receiving Information: Different Communication Modes in Gathering Voter Information}

(A) Telephone Calls and Face-to-Face Survey: A substantial survey is a purposeful research that can help candidates gather valid and reliable data to plan the strategy in an election campaign (Kahn \& Cannel, 1957). In the 1970s, lots of researches were done to compare the effectiveness of telephone interviews and face-toface interviews (John, 1985). Besides that, for several reasons, the telephone canvassing process is expected to be more stressful and demanding than face-to-face canvassing. As a result, face-to-face interviews have a 
higher response rate than telephone interviews (Botwinick, 1978; \& Groves \& Kahn, 1979). Face-to-face surveys allow for personal communication and make it possible to gather more information for election study. According to Holbrook, Green, \& Krosnick, (2003), telephone respondents are more distrustful compared with face-to-face interviews.

Face-to-face communication may make them more comfortable in discussing sensitive issues; while telephone respondents are more embarrassed to do so. Additionally, face-to-face respondents are more likely to explain questions carefully than telephone respondents. Also, face-to-face respondents are more comfortable in revealing socially undesirable attitudes, beliefs, or opinions. Face-to-face communications provide a better environment rather than telephone communication that might distract the respondents. Therefore, fifty years ago, most of the good quality surveys were collected through face-to-face interviews. The result found out that telephone surveys suffer from a lower response rate (Weeks, Kulka, Lessler, \& Whitmore, 1983). Thus, in the last 50 years in America, most telephone interviewing is replaced by face-toface interviewing as the prevalent method of data collection.

(B) ICT versus Face-to-Face Communication: In the century of 1990s, with the use of advanced technology such as computers and cell phones, candidates and political parties are increasingly viewing technology as the more modernized mode of communication (Parry, Barth, Kropf, and Terrence, 2008). The use of advanced technology can enhance human interactions. For example, e-mail has its own uniqueness different from other communication channels. But some researchers found that face-to-face canvassing still is one of the important efforts in increasing turn-up support for the candidates among targeted individuals (Ibid). However, there are many ways ICT-mediated communication and face-to-face ones are comparable. CMC is defined as the interaction between individuals on the computer platform and is known for high levels of interactivity (Herring, 1996). Hence, it is important to investigate the communication and interactions in this context (Chapelle, 2003). Therefore, user preferences between face-to-face canvassing and CMC.

As well as their challenges, problems and effectiveness had been studied (Adam \& Galanes, 2009). The problems with face-to-face canvassing are time-consuming for data collection, staff requirement, most expensive method, requires skills communication. Face-to-face canvassing is an expensive method to promote the image of candidates and political parties in an election (Begley, 2004). Face-to-face canvassing in an election campaign requires the cost of travel for staff to knock on door-to-door of private residences. Also, it is very time-consuming for candidates and staff to visit the voters door-to-door (Ibid). In addition, geographical limitations can be difficult for campaign teams to reach in person because they are rarely at home and access to their home is restricted. Besides that, the costs of training staff for face-to-face canvassing are also high. Therefore, time and cost-effectiveness are a concern for face-to-face canvassing in an election campaign.

(C) Comparing Different Modes in Information Gathering: It is critical to examine face-to-face communication and ICT-mediated communication (Chapelle, 2003). For example, face-to-face contact elicits a higher response than email contacts (Goyder, 1985). As the result, mail surveys are considered not ideal for their low response rate compared with telephone and face-to-face methods. In addition, considerable works have been done to improve the face-to-face method in collecting information from the general public. Face-toface canvassing is a better result than other forms of communication (Chapelle, 2003). Besides that, some researchers also found that the mail survey obtained a considerably lower response rate than the face-to-face survey (Silver, Cohen, Crutchfield, 1994). The reason for the lower response rate for web-based surveys than face-to-face ones are that it is are self-administrated and respondents are more inclined to ignore the survey.

Moreover, the elderly ones are not familiar with internet technologies (Bayart \& Bonnel, 2012). Face-to-face respondents are more likely to provide the necessary attention or cognitive work to think on questions carefully, while telephone interviewers are less likely to spend the effort. The finding from Herzog, Rodgers and Kulka, (1983), face-to-face interviews usually capture a higher proportion of older age respondents who are otherwise feeling tired when interviewed through the phone. Therefore, face-to-face contact generates a higher response than other forms of communication (Stevens \& Benjamin, 2010). A face-to-face approach can mobilize the public better for campaigns such as recycling, donations and volunteering. In one study, telephone and face-to-face interviewing methods are used to obtain data on smoking in population-based 
large-scale surveys. As a result, respondents tended to report more often being a smoker in the face-to-face interview (Orna, Amalia, Green \& Nitzan, 2004).

Dissemination of Information: Face-to-Face Canvassing in Political Field: In the political field, the term face-to-face canvassing started in the last half-century (Katz \& Eldersveld, 1961). Traditionally face-to-face canvassing is done by politicians to tramp the streets from house to house, to persuade voters to come out and vote for it. Researchers showed that the campaign activities such as face-to-face canvassing are an important marketing tool to promote the image of the candidates and political parties in an election. Canvassing allows individual interaction to deliver a campaign message, brings the candidate's team to the streets and gives a personal touch. Besides that, canvassing helps to understand voters' needs and persuade uncertain voters (Wolfinger, 1974).

Thus, in the last half-century, election campaigns are strongly associated with canvassing to seek supports. This can probably be explained by researches that demonstrated that door-to-door canvassing can increase turnout and support in an election since the 1960s (Miller, David \& Denise, 1981). There is a strong influence on voters' decisions after face-to-face canvassing in an election campaign (Cutright, 1963). Besides that faceto-face communication had been practiced for a long time ago. Face-to-face communications give people maximum opportunities to raise questions, voice criticisms, and feedback to government officials. During face-to-face canvassing, candidates can introduce to voters to identify potential supporters and listening voters' demands (Dillman, 1978). This allows candidates to identify whether a voter is a support to particular candidates. Door-to-door canvassing also helps the candidates to collect information and predict whether the voters are intended to vote in the coming election. Having voter preference insights at the beginning stage of the election campaign provides advantages. This enables a campaign team to locate their base supporters and conservative voters. The most efficient method to know voters in a precinct is to do it directly by asking voters at their door who they are supporting and what issues are important to them (Canale \& Swain, 1980). In addition, candidates are able to plan the strategy to persuade undecided voters.

The superiority of Face-to-Face Contacts: Face-to-face approach is more welcomed by the voters and canvassers tend to be more likely to promote the image in an election (Ramirez, 2008). Many researchers agreed that face-to-face canvassing by candidates, parties, and groups, is an important marketing tool to promote the image of candidates and gain support from voters (Niven, 2004; \& Hillygus, 2005). Face-to-face canvassing provides more superior results than other modes (Stevens \& Benjamin, 2010). It is popular and effective largely for these two main reasons, both of which are related to verbal and non-verbal communications:

(A) Trust-Building: Face-to-face communication is the best way to build a relationship with each other. A good relationship promotes trust and respect between each other. Building trust is one of the most important things in a relationship today (Lewicki, \& Bunker, 1996). Therefore, Lionel, Dennis, and Hung, (2009) have mentioned that the communication environment through face-to-face influences a team member's willingness to engage in trusting behavior. They argue that face-to-face teams showed higher trust and exchanged information than ICT-mediated teams. Besides that, face-to-face canvassing provides candidates and voters chances to build transparency (Lewicki \& Bunker, 1996). The most important task of a candidate is to gain trust, and the most effective way to achieve it is through body language (Alge, Wiethoff, \& Klein 2003). Over the telephone or internet, the candidates and voters cannot see each other and there is always the trust and suspicion aspect. Eye contact during face-to-face canvassing makes voters believe that the politicians are telling the truth which is likely the key advantage of this method. Many feel comfortable in the process of actual interaction. Candidate-voters' human contact is a basic human need (Ibid). Face-to-face communication boosts better expression of ideas and emotions than choosing letters, emails or phones for communication (Mayer, Davis, \& Schoorman, 1995). Candidates can resort to eye contact and non-verbal language in the expression of ideas.

Smiling makes candidates appear to be friendlier to the voter. In general, the more face-to-face contact candidate has with voters the better services are promoted. Body language communication is more important than words. Furthermore, face-to-face canvassing is one of the most effective ways to promote a good impression for political parties and candidates (Begley, 2004). According to Davis (1975), different settings 
cause residents to respond differently to a stranger at their doors. He concludes that the possible response levels of interaction are: 1 . Residents are at home but ignore a visitor. 2. Responding behind the door or through a peephole. 3. Response through a chain. 4. Responding by opening the door and 5. Inviting interviewer to home. Therefore, in a different kind of situation, the candidates and political parties need different strategies to gain support from voters. The candidates go from door to door, talking to individual voters individually to know their problems faced. It allows the candidates to send their message to voters and assess the amount of support they can get (Gerber \& Green, 2001). It sends the message that the candidates are caring enough to talk to voters one on one. Usually, voters are impressed by a candidate's visit. In addition, according to Begley (2004), hearing political messages more than once reinforces voters' memory. Hence, increasing the number of home visits improves a candidate's image. Therefore, door-to-door canvassing is crucial to win support from voters.

(B) Two-Way Communications: The advantages of candidates going face-to-face canvassing are to get correct information from voters. During face-to-face canvassing, candidates can introduce him or her to the voters and identify potential supporters. One of the most important parts of communication is listening. This allows candidates to identify whether a voter is to support his or her. Door-to-door canvassing also helps the candidates to predict whether the voters intend to vote in the upcoming election (Ibid). Candidates are able to plan the strategy to persuade voters and gain support from them (Silvia, 2002). Therefore, door-to-door canvassing is a highly targeted technique (Ramirez, 2008). In addition, face-to-face canvassing enables candidates to share their decisions with voters. Through face-to-face canvassing, the candidates are able to notice that the information is sent to the correct person. Meeting such needs with emailing or teleconferences is not possible. Thus, the exchange of information and indicating one's attitudes on certain societal issues can help the candidates to collect information for planning ones' strategy to gain support from voters (Gerber, Green, \& Nickerson, 2003). The voters will be able to listen and ask for clarification about things that they don't understand.

Admittedly, this approach is time-consuming instead of immediately sending an email. Nevertheless, candidates and voters also take a great deal of time to interpret each other ideas clearly in an email (Walther, 1995). An e-mail message can be interpreted differently by different individuals. Miscommunication can cause more time waste (Ryan, Carlton \& Ali, 1999). Fortunately, face-to-face contact avoids such issues by facilitating confusion clarification and rapport. It helps candidates and voters to understand each other better. There are some positive psychological perspectives about face-to-face canvassing's unique advantages (Alge, Wiethoff, \& Klein 2003). Face-to-face canvassing allows voters to behold both verbal and non-verbal behavioral cues not available in many ICT channels. For example, the voice quality and volume of voters, facial expressions of voters, are not available in email or chat rooms. Videoconferencing cannot capture all real-life interaction dynamics. Anderson, Bard, Sotillo, Newlands, \& Doherty (1997) has mentioned that in face-to-face conversation, facial expressions provide more clues than the tone of voice in their actual response.

Furthermore, in the rapid development of technology, social psychological research suggests that face-to-face mode is useful in inducing compliance to promote the image of the candidates and political parties. Research in political psychology indicated that personal interactions, such as face-to-face canvassing, are more impactful than group-based messages which are impersonal. Impersonal contact is less effective. Besides that, for a number of reasons, the telephone canvassing procedure is more stressful and challenging (Burgess, Haney, Snyder, Sullivan, \& Transue, 2000). The telephone method is inconvenient with regards to coverage such as the absence of home phones in remote areas, or reliance on mobile phones of urban residents (Blumberg, Luke, Cynamon \& Frankel, 2008). It should be pointed out that certain information collection failures such as unsuccessful calls and the overrepresentation of others can jeopardize information accuracy. Hence, face-to-face canvassing enable paying attention to voters' mood and emotions, thus candidate can decide if they should continue, persuade or terminate the discussion.

Face-to-Face Canvassing in Malaysia: In Malaysia, some researchers studied the importance of face-to-face canvassing in communication (Gurnam \& Ranjit, 2010) with results mirrored that of Western countries. Among the advantages of face-to-face canvassing are immediate response, two-way communication, more cues and suitable for rapport building. They have shown that even though CMC has been used as a 
communication medium in Malaysia but face-to-face interaction is still more effective. In Malaysia, any citizen of 21 years old or above is entitled to register under the Election Commission as a voter (Harun, 1998). Usually, such registration exercise is carried out once a year, although more can be held if the Election Commission sees the need. A detailed voter registration campaign is the first step before executing a voter contact program. Voter registration is important to increase voter turnout in a specific area, utilize unused resources, and establish the foundation of a campaign. The voter registration programs are set based on specific objectives. The campaign helps candidates to know the number of votes one needs to win and meet other goals. Thus, this study will focus on appropriate communication such as face-to-face canvassing is an important tool to promote the image of candidates and political parties in an election.

\section{This Project}

Since Malaysia achieved independence in 1957, Penang has consistently been holding a general election every five years as a democratic practice to form a competitive state government. In Penang, state governments are headed by the Chief Minister, usually the leader of the winning party or coalition in DUN. The comparative method is used in the research to compare both Barisan Nasional (BN) and Pakatan Rakyat (PR) in using faceto-face canvassing as an effective tool to promote their party image in the election. Both political coalitions in Penang are similar in some respects. For example, Barisan Nasional consists of (UMNO, MCA, Gerakan and MIC) and Pakatan Rakyat consists of (Keadilan, DAP and PAS). UMNO and PKR mainly depend on Malay people to secure their DUN seats. Besides that MCA, Gerakan and DAP mainly depend on Chinese voters to secure the seats in Penang and with the help of Indian voters. Besides that, PAS is mainly supported by Malay voters who wish to establish our country as an Islamic nation according to Islamic legal theory. Each of the political parties has its own ideologies, images that cater to different supporter segments. Therefore, BN and PR are good examples to compare and study to find out if face-to-face canvassing is a useful tool to promote the images of candidates and political parties. BN and PR are equally strong political parties in Penang. The goal of this research is to find out which political parties in Penang showed that face-to-face canvassing is the best way to improve the image in the coming election.

In a comparative study, face-to-face canvassing is examined in these 2 political parties. BN emerged as the biggest winner in Penang year of 1999 and year of 2004. In the year 1999, there are 11 parliament constituencies in Penang, 6 out of 11 parliament seats (55\%) is won by BN and only 5 out of 11 parliament seats (45\%) were won by the opposition party. The difference of parliament seats between BN and PR is \pm 1 . In the year 2004, 8 out of 13 parliament seats (62\%) is won by BN and only 5 out of 13 parliament seats (38\%) were won by the opposition party. The difference of parliament seats between BN and PR is \pm 2 . On the other hand, the political tsunami in the year 2008 caused PR to emerge as the biggest winner in Penang and took 11 out of 13 parliament seats (85\%) in the 12th general election and only 2 out of 11 parliament seats (15\%) were won by the BN. The difference of parliament seats between BN and PR is \pm 5 . From the history of the election result, both parties (BN and PR) emerged as strong political parties in Penang. Therefore, the scope of this study is further limited to politicians and candidates under BN and PR in the state of Penang. This state (Penang) is appropriate to conduct the research as the sample used reflects the characteristics of ethnic politics in West Malaysia. The tools applied by politicians and political parties such as face-to-face canvassing will be recorded. During the process of analysis, a comparison of the political parties will be study and the findings will be generalized.

\section{Conclusion}

In conclusion, the core of political marketing is about understanding voters' needs and catering for those needs, of the three political marketing models, MOP is specifically targeting this goal, making it the most useful model. Within the MOP process, communication occupies a special place where the success of MOP is contingent upon the effectiveness of party-voter communication. These communications are especially important in the first step when gathering voter information and in the final step when building party image during an election campaign. From the literature review presented above, it is clear that although ICT communication enables many benefits face-to-face communication remains advantageous in many aspects. Lastly, the project's justification for using a comparative approach is also explained. 


\section{References}

Adam, K. \& Galanes, G. (2009). Communicating in groups: Application and skills (6th Ed.). New York: McGraw Hill.

Alge, B. J., Wiethoff, C. \& Klein, H. J. (2003). When does the medium matter? Knowledge-building experiences and opportunities in decision-making teams. Organizational Behavior and Human Decision Processes, 91(1), 26-37.

Anderson, A. H., Bard, E. G., Sotillo, C., Newlands, A. \& Doherty, S. G. (1997). Limited visual control of the intelligibility of speech in face-to-face dialogue. Perception \& Psychophysics, 59(4), 580-592.

Baines, P. R., Harris, P. \& Lewis, B. R. (2002). The political marketing planning process: Improving image and message in strategic target areas.

Bayart, C. \& Bonnel, P. (2012). Challenges? Transportation, 39(1), 1147-1171.

Begley, K. A. (2004). Face-to-face communication: Making human connections in a technology-driven world. Canada: Crisp Learning.

Blumberg, S. J., Luke, J. V., Cynamon, M. L. \& Frankel, M. (2008). Recent trends in household telephone coverage in the United States. New York: Willey.

Botwinick, J. (1978). Aging and behavior (2nd Ed.). New York: Springer.

Burgess, D., Haney, B., Snyder, M., Sullivan, J. L., \& Transue, J. E. (2000). Rocking the vote: Using personalized messages to motivate voting among young adults. Public Opinion Quarterly, 64,29-52.

Canale, M. \& Swain, M. (1980). Theoretical bases of communicative approaches to second language teaching and testing. Applied Linguistics, 11(1), 1-47.

Chapelle, C. (2003). English language learning and technology. Amsterdam: John Benjamins Publishing Company.

Cutright, P. (1963). Measuring the impact of local party activity on the general election vote. Public Opinion Quarterly, 27(1), 372-386.

Dillman, D. A. (1978). Mail and telephone surveys: The total design method. New York: Wiley Publication.

Gerber, A. S. \& Green, D. P. (2000). The effects of canvassing, direct mail, and telephone contact on voter turnout: A field experiment. American Political Science Review, 94(9), 653-663.

Gerber, A. S. \& Green, D. P. (2001). Do phone calls increase voter turnout? A field experiment. Public Opinion Quarterly, 65(1), 75-85.

Gerber, A. S., Green, D. P. \& Larimer, C. W. (2008). Social pressure and voter turnout: Evidence from a field experiment. American Political Science Review, 102(1), 33-48.

Goyder, J. (1985). Face-to-face interviews and mailed questionnaires: The net difference in response rate. The Public Opinion Quarterly, 49(2), 234-252.

Groves, R. M., \& Kahn, R. L. (1979). Surveys by telephone: A national comparison with personal interviews. New York, NY: Academic Press.

Gurnam, K. S. \& Ranjit, K. (2010). Learner autonomy via asynchronous online interactions: A Malaysian perspective. International Journal of Education and Development using Information and Communication Technology, 6(3), 88-100.

Harrop, M. (1990). Political Marketing, Parliamentary Affairs, Oxford University Press, Oxford.

Harun, D. (1998). Voting for democracy. Retrieved from http://aceproject.org/ero-en/topics/voterregistration/vrx_w009.pdf/view

Herring, S. C. (1996). Linguistic and critical research on computer-mediated communication: Some ethical and scholarly considerations. The Information Society, 12(2), 153-168.

Herzog, A. R., Rodgers, W. L. \& Kulka, R. A. (1983). Interviewing older adults: A comparison of telephone and face-to-face modalities. The Public Opinion Quarterly, 47(3), 405-418.

Heufers, R. (2002). The Politics of Democracy in Malaysia. ASIEN, 85, 39-60.

Hillygus, D. S. (2005). Campaign effects and the dynamics of turnout intention in election 2000. Journal of Politics, 67(1), 50-68.

Holbrook, A. L., Green, M. C. \& Krosnick, J. A. (2003). Telephone versus face-to-face interviewing of national probability samples with long questionnaires: Comparisons of respondent satisfying and social desirability response bias. The Public Opinion Quarterly, 67(1), 79-125.

Hornby, A. S., Wehmeier, S., Mclntosh, C., Turnbull, J. \& Ashby, M. (2005). Oxford advanced learner's dictionary. New York: Oxford Universities Press. 
John, G. (1985). Face-to-face interviews and mailed questionnaires: The net difference in response rate. The Public Opinion Quarterly, 49(2), 234-252.

Jonassen, D. \& Kwon, H. (2001). Communication patterns in computer-mediated versus face-to-face group problem-solving. Educational Technology Research and Development, 49(10), 35-52.

Kahn, R. L. \& Cannell, C. F. (1957). The psychological basis of the interview. The dynamics of interviewing: Theory, technique, and cases. New York: John Wiley \& Sons.

Katz, D. \& Eldersveld S. J. (1961). The impact of party activity upon the electorate. Public Opinion Quarterly, 25(1), $1-24$.

Kavanagh, D. (1995). Election campaigning: the new marketing of politics. Oxford: Blackwell Publishers

Kavanagh, D. (1996). New campaign communications: consequences for political parties. Harvard International Journal of Press and Politics, 1(3), 60-76.

Lees-Marshment, J. (2001a). The product, sales and market-oriented party: how labor learned to market the product, not just the presentation. European Journal of Marketing, 35(9-10), 1074-1084

Lees-Marshment, J. (2001b). The marriage of politics and marketing. Political Studies, 49, 692-713.

Lewicki, R. J. \& Bunker, B. B. (1996). Developing and maintaining trust in work relationships. Thousand Oaks: Sage Publication.

Lionel, P. R., Dennis, A. L. \& Hung, Y. T. (2009). Individual swift trust and knowledge-based trust in face-toface and virtual team members. Journal of Management Information Systems, 26(2), 241-279.

Manikas, P.M. \& Thornton, L. L. (2003). Political Parties in Asia. National Democratic Institute for International Affairs, Washington, DC.

Mayer, R. C., Davis, J. H. \& Schoorman, F. D. (1995). An integrative model of organizational trust. Academy of Management Review, 20(3), 709-734.

Meijden, H. V. \& Veenman, S. (2005). Face-to-face versus computer-mediated communication in a primary school setting. Computers in Human Behavior, 21(1), 831-859.

Miller, R. (2009). Organizational communication: Approaches and process (5th Ed.). United States of America: Wadsworth Publication.

Miller, R., David, B. \& Denise, B. (1981). Stimulating voter turnout in a primary: Field experiment with a precinct committeeman. International Political Science Review, 2(4), 445-600.

Niven, D. (2004). The mobilization solution? Face-to-face contact and voter turnout in a municipal election. Journal of Politics, 66(1), 868-884.

Orna, B. E., Amalia, H. M., Green, M. S. \& Nitzan, K. D. (2004). Ethnic differences in reported smoking behaviors in face-to-face and telephone interviews. European Journal of Epidemiology, 19(7), 679-686.

Parry, J., Barth, J., Kropf, M. \& Terrence J. E. (2008). Mobilizing the seldom voter: Campaign contact and effects in high-profile elections. Political Behavior, 30(1), 97-113.

Piccoli, G. \& Ives, B. (2003). Trust and the unintended effects of behavior control in virtual teams. MIS Quarterly, 27(3), 365-395.

Provenzo, E. F. (1986). Beyond the Gutenberg galaxy. New York: Teachers College Press.

Ramirez, R. (2008). Residential mobility and the political mobilization of Latinos in Houston. Charlottesville: University of Virginia Press.

Ryan, M., Carlton, K. H. \& Ali, N. S. (1999). Evaluation of traditional classroom teaching methods versus course delivery via the world wide web. Journal of Nursing Education, 3(6), 273-277.

Scammell, M. (1995). Designer Politics How Elections are Won. ST. Martin's Press, Inc.,

Silver, S. D., Cohen, B. P. \& Crutchfield, J. H. (1994). Status differentiation and information exchange in face-toface and computer-mediated idea generation. Social Psychology Quarterly, 57(2), 108-123.

Silvia, P. (2002). Communicatorsimilarity and persuasion: Exploring a balance model (Doctoral dissertation). University of Kansas.

Smith, T. W. (1995). Trends in non-response rates. Journal of Public Opinion, 7(1), 157-171.

Stevens, D. \& Benjamin, G. B. (2010). Getting out the vote: Minority mobilization in a presidential election. Political Behavior, 33(1), 113-138.

The Star Online. (2008). General Election 2008 Results.

Walther, J. B. (1995). Relational aspects of computer-mediated communication: Experimental observations over time. Organization Science, 6(2), 186-203.

Weeks, M. F., Kulka, R. A., Lessler, J. T. \& Whitmore, R. W. (1983). Personal versus telephone surveys for collecting household health data at the local level. American Journal of Public Health, 73(13), 89-94. 
Wielhouwer, P. W. (2000). Releasing the fetters: Parties and mobilization of the African-American electorate. The Journal of Politics, 62(1), 206-222.

Wolfinger, R. E. (1974). The politics of progress. Englewood Cliffs: Prentice-Hall.

Wring, D. (1997). Reconciling Marketing with Political Science: Theories of Political Marketing. Proceedings of the 1997 Academy of Marketing Conference, Manchester, 1131-1144. 